\title{
The phosphate mineral arrojadite-(KFe) and its spectroscopic characterization
}

\author{
Ray L. Frost ${ }^{a, *}$, Yunfei Xi ${ }^{a}$, Ricardo Scholz ${ }^{b}$, Laura Frota Campos Horta ${ }^{b}$

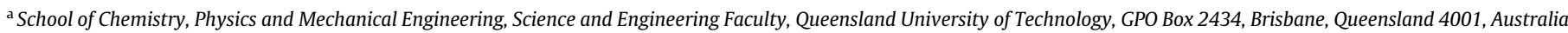 \\ ${ }^{\mathrm{b}}$ Geology Department, School of Mines, Federal University of Ouro Preto, Campus Morro do Cruzeiro, Ouro Preto, MG 35,400-00, Brazil
}

\section{H I G H L I G H T S}

- We have undertaken a study of the arrojadite-(KFe) mineral.

- Electron probe analysis shows the formula of the mineral is complex.

- The complexity of the mineral formula is reflected in the vibrational spectroscopy.

- Vibrational spectroscopy enables new information about this complex phosphate mineral arrojadite to be obtained.

\section{A R T I C L E I N F O}

\section{Article history:}

Received 22 October 2012

Received in revised form 6 February 2013

Accepted 12 February 2013

Available online 27 February 2013

\section{Keywords:}

Arrojadite

Phosphate

Raman spectroscopy

Infrared spectroscopy
G R A P H I C A L A B S T R A C T

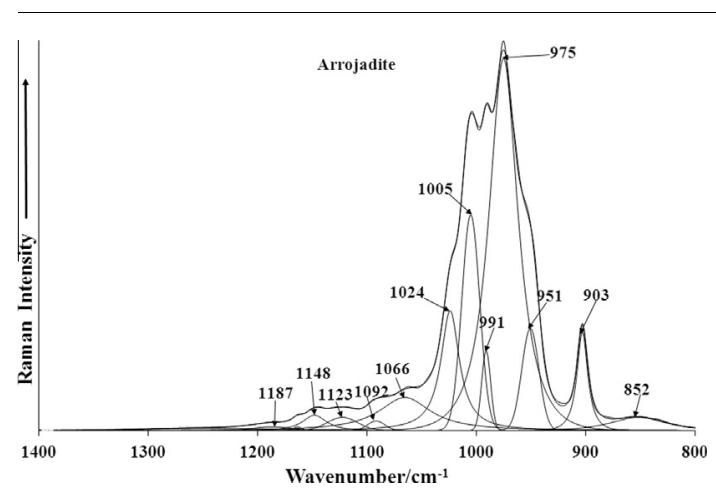

\begin{abstract}
A B S T R A C T
The arrojadite-( $\mathrm{KFe})$ mineral has been analyzed using a combination of scanning electron microscopy and a combination of Raman and infrared spectroscopy. The origin of the mineral is Rapid Creek sedimentary phosphatic iron formation, northern Yukon. The formula of the mineral was determined as $\mathrm{K}_{2.06} \mathrm{Na}_{2} \mathrm{Ca}_{0.89} \mathrm{Na}_{3.23}\left(\mathrm{Fe}_{7.82} \mathrm{Mg}_{4.40} \mathrm{Mn}_{0.78}\right)_{\Sigma 13.00} \mathrm{Al}_{1.44}\left(\mathrm{PO}_{4}\right)_{10.85}\left(\mathrm{PO}_{3} \mathrm{OH}_{0.23}\right)(\mathrm{OH})_{2}$.

The complexity of the mineral formula is reflected in the spectroscopy. Raman bands at 975, 991 and $1005 \mathrm{~cm}^{-1}$ with shoulder bands at 951 and $1024 \mathrm{~cm}^{-1}$ are assigned to the $\mathrm{PO}_{4}^{3-} v_{1}$ symmetric stretching modes. The Raman bands at 1024, 1066, 1092, 1123, 1148 and $1187 \mathrm{~cm}^{-1}$ are assigned to the $\mathrm{PO}_{4}^{3-} \mathrm{v}_{3}$ antisymmetric stretching modes. A series of Raman bands observed at 540,548, 557, 583, 604, 615 and $638 \mathrm{~cm}^{-1}$ are attributed to the $v_{4}$ out of plane bending modes of the $\mathrm{PO}_{4}$ and $\mathrm{H}_{2} \mathrm{PO}_{4}$ units. The $v_{2}$ $\mathrm{PO}_{4}$ and $\mathrm{H}_{2} \mathrm{PO}_{4}$ bending modes are observed at 403, 424, 449, 463, 479 and $513 \mathrm{~cm}^{-1}$. Hydroxyl and water stretching bands are readily observed. Vibrational spectroscopy enables new information about the complex phosphate mineral arrojadite-(KFe) to be obtained.
\end{abstract}

(c) 2013 Elsevier B.V. All rights reserved.

\section{Introduction}

The arrojadite mineral group is a complex group of phosphates with general chemical formula given as: $\mathrm{A}_{2} \mathrm{~B}_{2} \mathrm{Ca}_{1} \mathrm{Na}_{2+\chi} \mathrm{M}_{13-}$ $\mathrm{R}\left(\mathrm{PO}_{4}\right)_{11}\left(\mathrm{PO}_{3} \mathrm{OH}_{1-x}\right) \mathrm{W}_{2}$, where the site $\mathrm{A}$ is occupied by large and divalent cations ( $\mathrm{Ba}, \mathrm{Sr}, \mathrm{Pb}$ ) plus vacancy, or monovalent cations $(\mathrm{K}, \mathrm{Na})$. The $\mathrm{B}$ site is occupied by either small divalent cations (Fe, $\mathrm{Mn}, \mathrm{Mg}$ ) plus vacancy, or monovalent cations ( $\mathrm{Na}$ ). The $\mathrm{M}$ site is essentially occupied by $\mathrm{Fe}^{2+}$ or $\mathrm{Mn}^{2+}$ and possibility of substitu-

\footnotetext{
* Corresponding author. Tel.: +61 73138 2407; fax: +61 731381804

E-mail address: r.frost@qut.edu.au (R.L. Frost).
}

tion by $\mathrm{Mg}$, $\mathrm{Zn}$, Li. $\mathrm{R}$ are trivalent cations $\left(\mathrm{Al}, \mathrm{Fe}^{3+}\right)$ and $\mathrm{W}$ are $\mathrm{OH}^{-}$ and $\mathrm{F}^{-}$[1]. The nomenclature of arrojadite group was established by Chopin et al. [2].

The crystal structure of arrojadite was first described by Krutik et al. [3] and later refined by Merlino et al. [4], Moore et al. [5], Steele [6] and Cámara et al. [1]. The structure of a synthetic $\mathrm{Fe}^{3+}$ arrojadite was refined by Yakubovich et al. [7]. Arrojadite group minerals crystallizes in the monoclinic crystal system, Space Group Cc [1]. Unit cell parameters are variable between the members of the group, however refined data for arrojadite-(KFe) are still not available and are restricted to the data published by Lindberg [8]. 
Table 1

Chemical composition of arrojadite-(KFe) from the Rapid Creek, Yukon, Canada. $\mathrm{H}_{2} \mathrm{O}$ calculated by stoichiometry.

\begin{tabular}{lrc}
\hline Constituent & wt.\% & Number of cations \\
\hline $\mathrm{P}_{2} \mathrm{O}_{5}$ & 46.08 & 11.84 \\
$\mathrm{Fe}_{2} \mathrm{O}_{3}$ & 25.38 & 7.82 \\
$\mathrm{Na}_{2} \mathrm{O}$ & 9.06 & 5.33 \\
$\mathrm{MgO}$ & 7.16 & 4.40 \\
$\mathrm{Al}_{2} \mathrm{O}_{3}$ & 4.03 & 1.44 \\
$\mathrm{CaO}$ & 2.75 & 0.89 \\
$\mathrm{MnO}$ & 2.24 & 0.78 \\
$\mathrm{~K}_{2} \mathrm{O}$ & 2.20 & 2.06 \\
$\mathrm{H}_{2} \mathrm{O}$ & 1.10 & 2.23 \\
$\mathrm{Total}$ & 100.00 & 36.79 \\
\hline
\end{tabular}

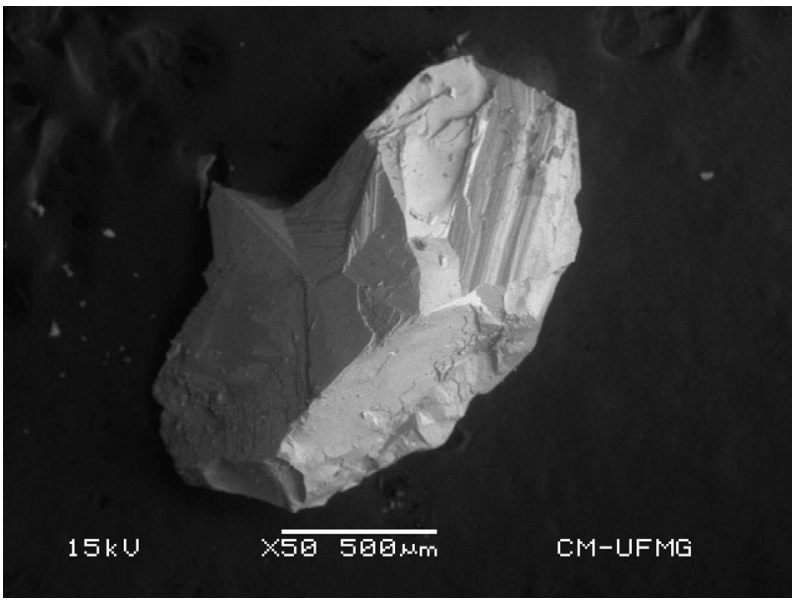

Fig. 1. Backscattered electron image (BSI) of arrojadite-(KFe) single crystal up to $2.0 \mathrm{~mm}$ in length.

In recent years, the application of spectroscopic techniques for the understanding the structure of phosphate minerals is increasing, with special attention to Al phosphates [9-12].

Farmer [13] divided the vibrational spectra of phosphates according to the presence, or absence of water and hydroxyl units. In aqueous systems, Raman spectra of phosphate oxyanions show a symmetric stretching mode $\left(v_{1}\right)$ at $938 \mathrm{~cm}^{-1}$, the antisymmetric stretching mode $\left(v_{3}\right)$ at $1017 \mathrm{~cm}^{-1}$, the symmetric bending mode $\left(v_{2}\right)$ at $420 \mathrm{~cm}^{-1}$ and the $v_{4}$ mode at $567 \mathrm{~cm}^{-1}$ [14-17]. The value for the $v_{1}$ symmetric stretching vibration of $\mathrm{PO}_{4}$ units as determined by infrared spectroscopy was given as $930 \mathrm{~cm}^{-1}$ (augelite), $940 \mathrm{~cm}^{-1}$ (wavellite), $970 \mathrm{~cm}^{-1}$ (rockbridgeite), $995 \mathrm{~cm}^{-1}$ (dufrénite) and $965 \mathrm{~cm}^{-1}$ (beraunite). The position of the symmetric stretching vibration is dependent upon the crystal chemistry of the mineral and is a function of the cation and crystal structure. The fact that the symmetric stretching mode is observed in the infrared spectrum affirms a reduction in symmetry of the $\mathrm{PO}_{4}$ units.

The value for the $v_{2}$ symmetric bending vibration of $\mathrm{PO}_{4}$ units as determined by infrared spectroscopy was given as $438 \mathrm{~cm}^{-1}$ (augelite), $452 \mathrm{~cm}^{-1}$ (wavellite), 440 and $415 \mathrm{~cm}^{-1}$ (rockbridgeite), 455,435 and $415 \mathrm{~cm}^{-1}$ (dufrénite) and 470 and $450 \mathrm{~cm}^{-1}$ (beraunite). The observation of multiple bending modes provides an indication of symmetry reduction of the $\mathrm{PO}_{4}$ units. This symmetry reduction is also observed through the $v_{3}$ antisymmetric stretching vibrations. Augelite shows infrared bands at 1205, 1155, 1079 and $1015 \mathrm{~cm}^{-1}$ [18]; wavellite at 1145, 1102, 1062 and $1025 \mathrm{~cm}^{-1}$; rockbridgeite at 1145,1060 and $1030 \mathrm{~cm}^{-1}$; dufrénite at 1135 , 1070 and $1032 \mathrm{~cm}^{-1}$; and beraunite at 1150, 1100, 1076 and $1035 \mathrm{~cm}^{-1}$.

In this work, spectroscopic investigation of monomineral arrojadite-(KFe) sample from Rapid Creek, Yukon, Canada has been carried out. The analysis includes spectroscopic characterization of the structure with infrared and Raman spectroscopy. Chemical analysis was applied to support the mineral characterization.

\section{Experimental}

\section{Samples description and preparation}

The arrojadite-(KFe) sample forms part of the collection of the Geology Department of the Federal University of Ouro Preto, Minas Gerais, Brazil, with sample code SAB065. The sample was gently crushed and the associated minerals were removed under a stereomicroscope Leica MZ4. The arrojadite-(KFe) sample was phase analyzed by X-ray diffraction.

The Rapid Creek sedimentary phosphatic iron formation comprises the upper and youngest portion of an Aptian-Albian flyschoid sequence which reaches a maximum thickness of $4 \mathrm{~km}$

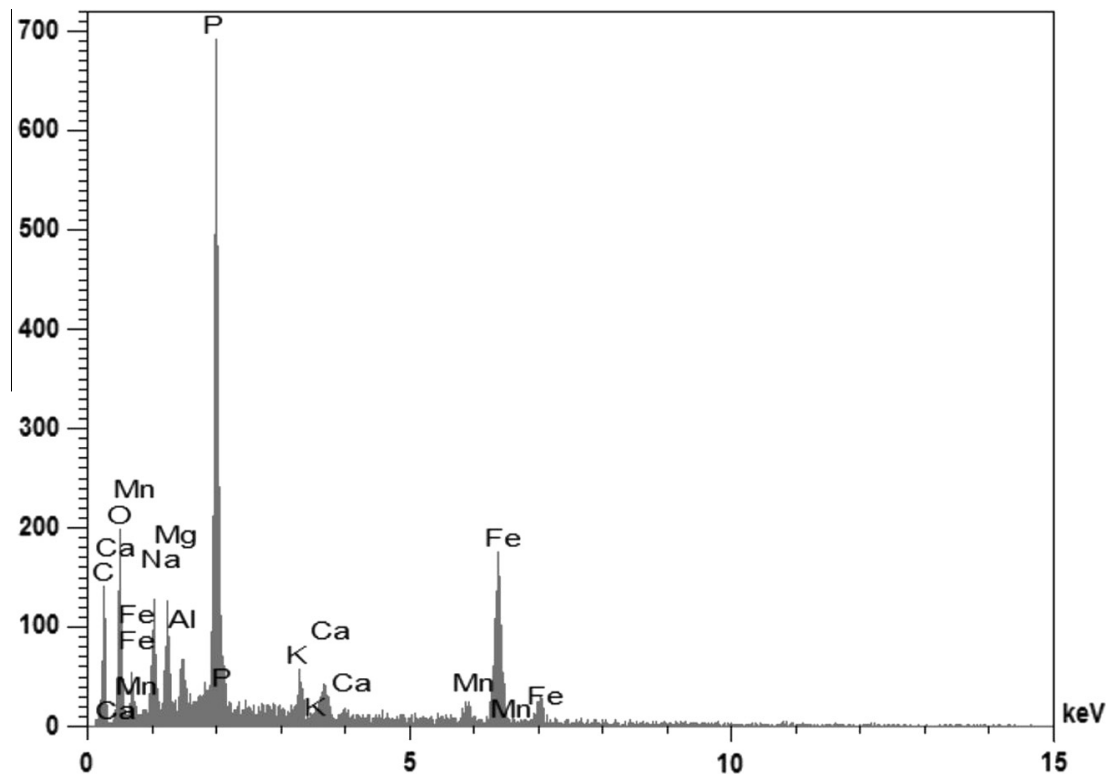

Fig. 2. EDS spectra of arrojadite-(KFe). 
(a)

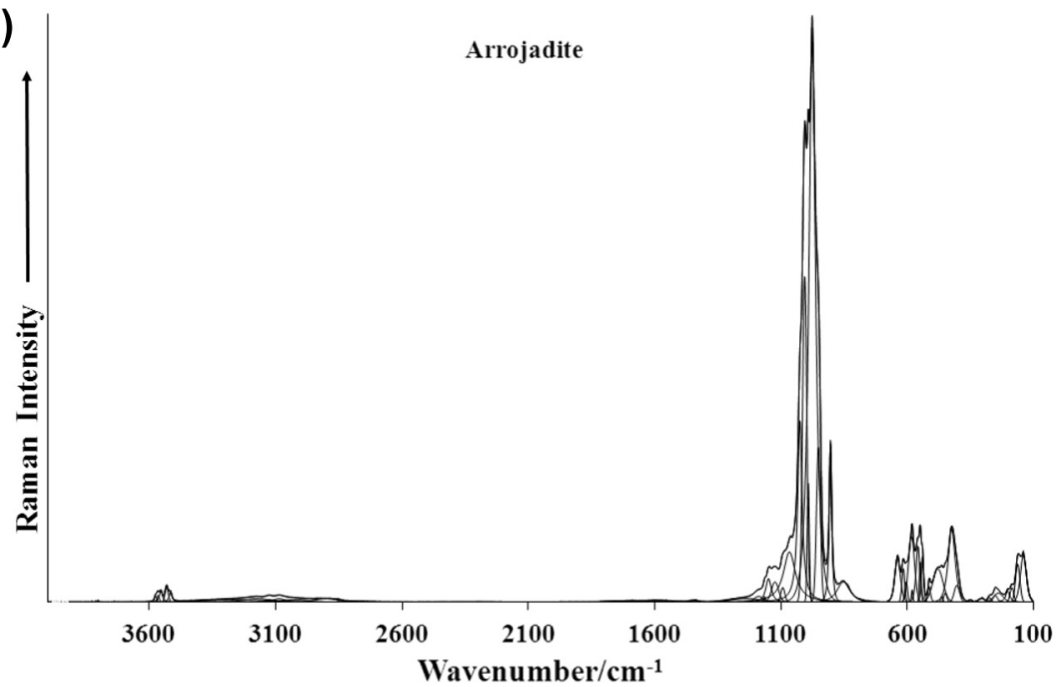

(b)

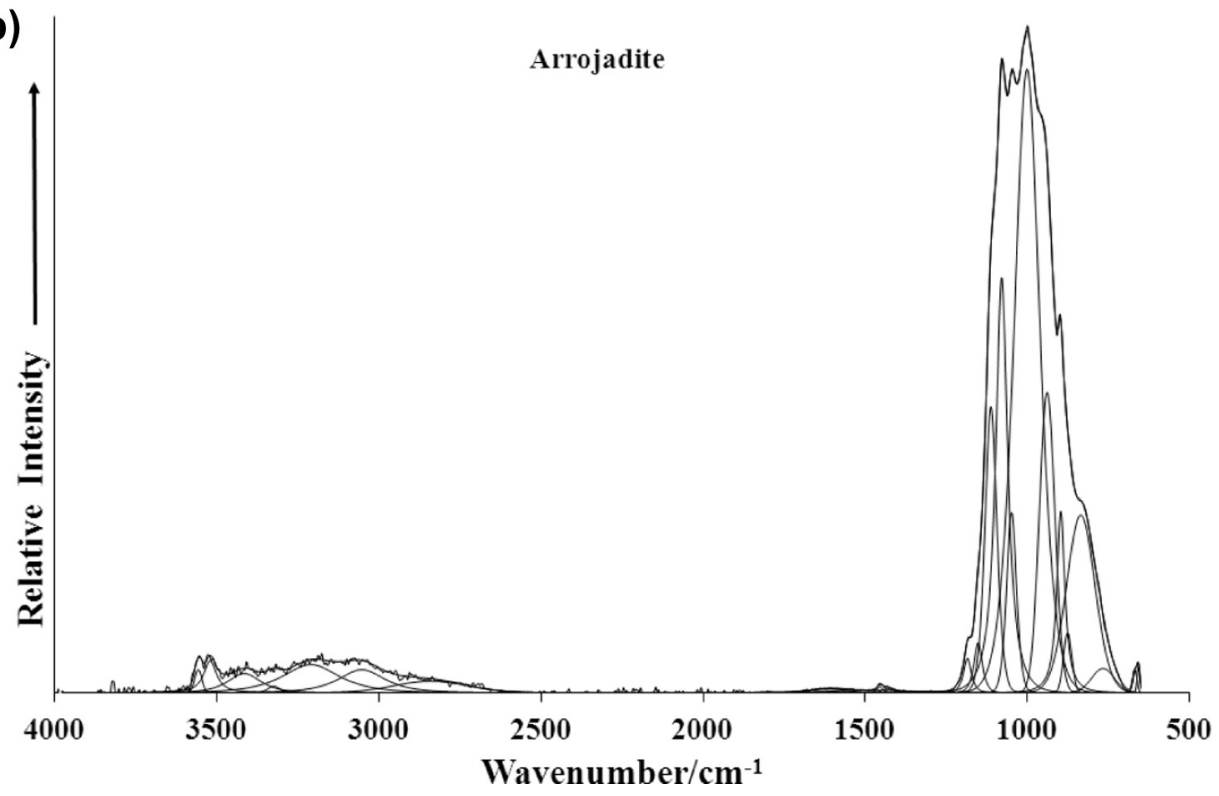

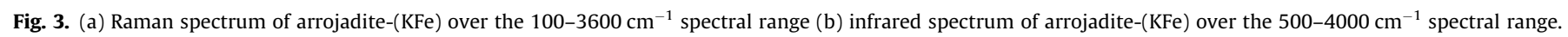

in the Blow Trough. The phosphate association is composed mainly of rare minerals such as satterlyite, arrojadite group minerals, augelite, lazulite and gormanite, which reflect an original calciumdeficient composition. The deposition of iron and magnesium phosphates as well as apatite is strongly indicated, and this condition is unique for marine phosphorites [19].

\section{Scanning electron microscopy (SEM)}

Arrojadite-(KFe) crystals were coated with a $5 \mathrm{~nm}$ layer of evaporated carbon. Secondary Electron and Backscattering Electron images were obtained using a JEOL JSM-6360LV equipment. Qualitative and semi-quantitative chemical analyses in the EDS mode were performed with a ThermoNORAN spectrometer model Quest and was applied to support the mineral characterization.

\section{Raman microprobe spectroscopy}

Crystals of arrojadite-(KFe) were placed on a polished metal surface on the stage of an Olympus BHSM microscope, which is equipped with $10 \times, 20 \times$, and $50 \times$ objectives. The microscope is part of a Renishaw 1000 Raman microscope system, which also in- cludes a monochromator, a filter system and a CCD detector (1024 pixels). The Raman spectra were excited by a Spectra-Physics model $127 \mathrm{He}-\mathrm{Ne}$ laser producing highly polarized light at $633 \mathrm{~nm}$ and collected at a nominal resolution of $2 \mathrm{~cm}^{-1}$ and a precision of $\pm 1 \mathrm{~cm}^{-1}$ in the range between 200 and $4000 \mathrm{~cm}^{-1}$. Repeated acquisitions on the crystals using the highest magnification $(50 \times)$ were accumulated to improve the signal to noise ratio of the spectra. Raman Spectra were calibrated using the $520.5 \mathrm{~cm}^{-1}$ line of a silicon wafer. The Raman spectrum of at least 10 crystals was collected to ensure the consistency of the spectra.

An image of the arrojadite-(KFe) crystals measured is shown in the supplementary information as Fig. S1. Clearly the crystals of arrojadite-(KFe) are readily observed, making the Raman spectroscopic measurements readily obtainable.

\section{Infrared spectroscopy}

Infrared spectra were obtained using a Nicolet Nexus 870 FTIR spectrometer with a smart endurance single bounce diamond ATR cell. Spectra over the $4000-525 \mathrm{~cm}^{-1}$ range were obtained by the co-addition of 128 scans with a resolution of $4 \mathrm{~cm}^{-1}$ and a mirror velocity of $0.6329 \mathrm{~cm} / \mathrm{s}$. Spectra were co-added to improve the signal to noise ratio. 
(a)

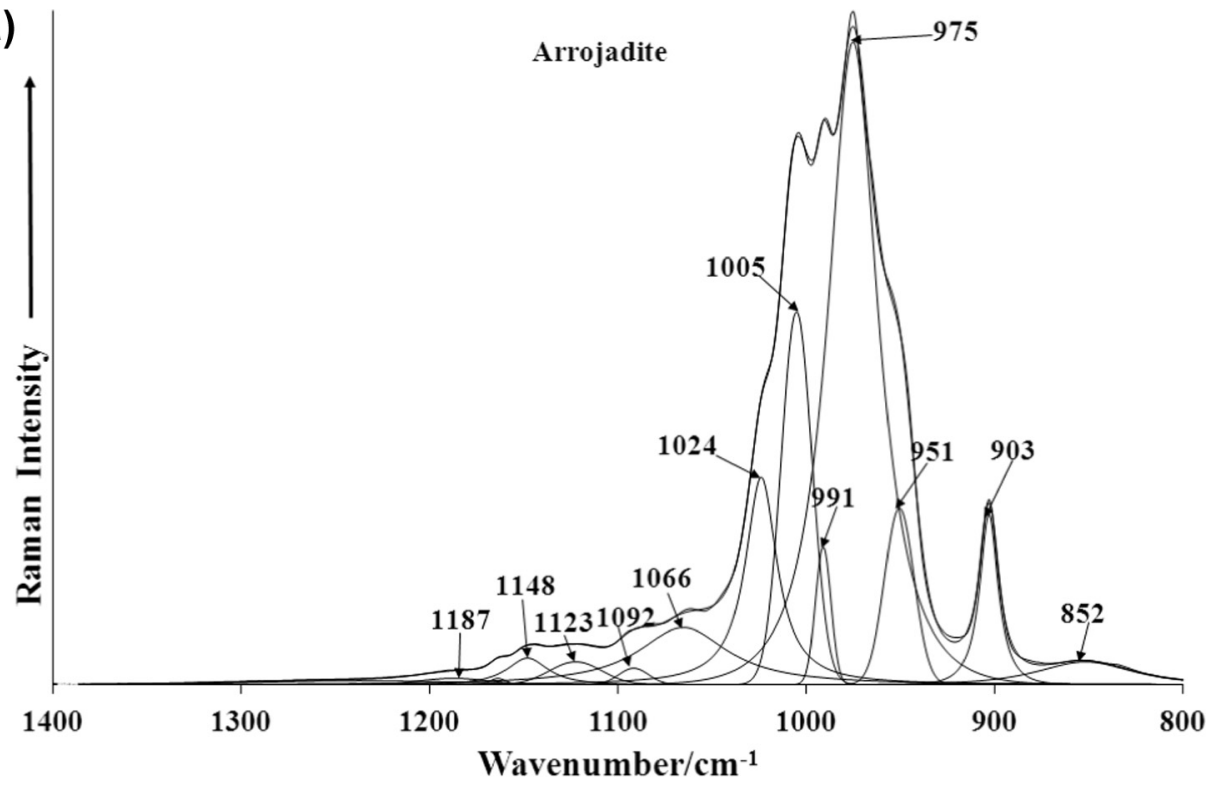

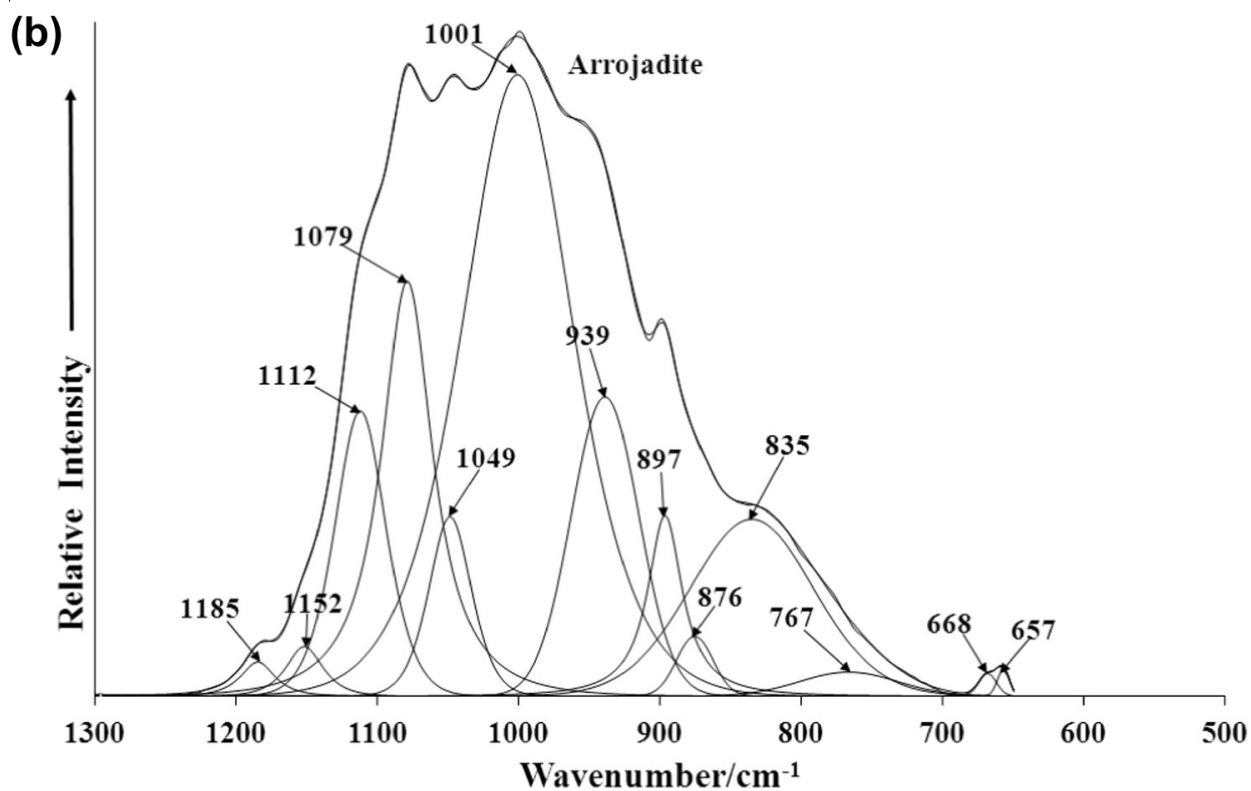

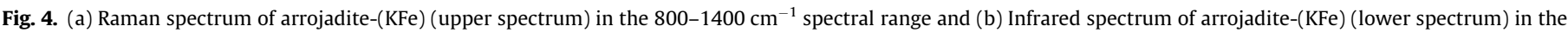
$500-1300 \mathrm{~cm}^{-1}$ spectral range.

Spectral manipulation such as baseline correction/adjustment and smoothing were performed using the Spectracalc software package GRAMS (Galactic Industries Corporation, NH, USA). Band component analysis was undertaken using the Jandel 'Peakfit' software package that enabled the type of fitting function to be selected and allows specific parameters to be fixed or varied accordingly. Band fitting was done using a Lorentzian-Gaussian cross-product function with the minimum number of component bands used for the fitting process. The Gaussian-Lorentzian ratio was maintained at values greater than 0.7 and fitting was undertaken until reproducible results were obtained with squared correlations of $r^{2}$ greater than 0.995 .

\section{Results and discussion}

\section{Chemical characterization}

The back scattered electron image (BSI) of arrojadite-(KFe) sample studied in this work is shown in Fig. 1. The fragment shows homogeneous composition. Qualitative and semi-quantitative chemical composition shows a complex Fe, $\mathrm{K}, \mathrm{Na}, \mathrm{Mg}$ and $\mathrm{Al}$ phosphate and with minor amounts of $\mathrm{Ca}$ and $\mathrm{Mn}$. Fluorine was not observed and the mineral is considered as $\mathrm{OH}$ end member. The semi-quantitative chemical data were recalculated considering $1.10 \%$ of $\mathrm{H}_{2} \mathrm{O}$ in the structure, as expected for the arrojadite-(KFe) end member. The $M$ site was recalculated on the basis of 13 cations. According to the crystal structure, $100 \%$ of $\mathrm{Fe}$ was considered as $\mathrm{Fe}^{2+}$. The EDS spectra of arrojadite-(KFe) and its chemical analysis is shown in Fig. 2. The chemical formula was calculated on the basis of $50 \mathrm{O}$ atoms $(\mathrm{O}, \mathrm{OH})$ and can be expressed as:

$$
\begin{aligned}
& \mathrm{K}_{2.06} \mathrm{Na}_{2} \mathrm{Ca}_{0.89} \mathrm{Na}_{3.23}\left(\mathrm{Fe}_{7.82} \mathrm{Mg}_{4.40} \mathrm{Mn}_{0.78}\right)_{\Sigma 13.00} \mathrm{Al}_{1.44}\left(\mathrm{PO}_{4}\right)_{10.85}\left(\mathrm{PO}_{3} \mathrm{OH}_{0.23}\right) \\
& \times(\mathrm{OH})_{2} .
\end{aligned}
$$

The results indicate an arrojadite-(KFe) mineral. The chemical analysis is given in Table 1 . 
(a)

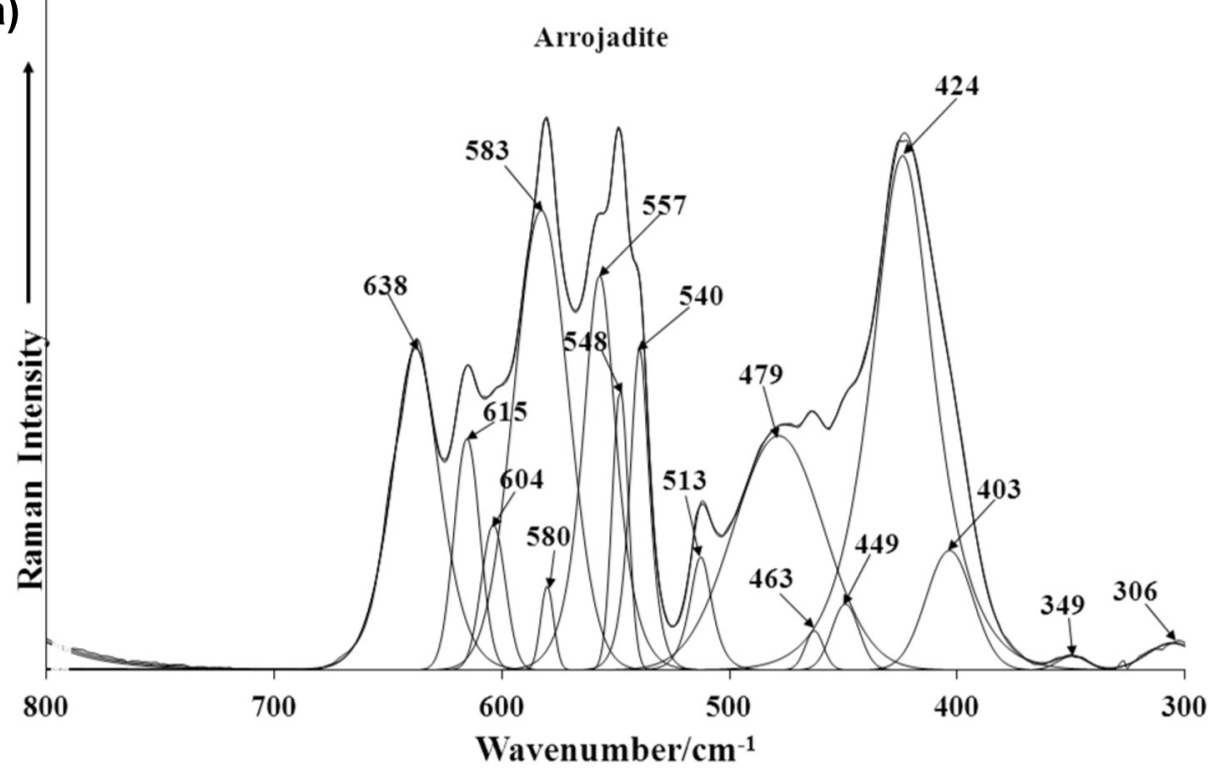

(b)

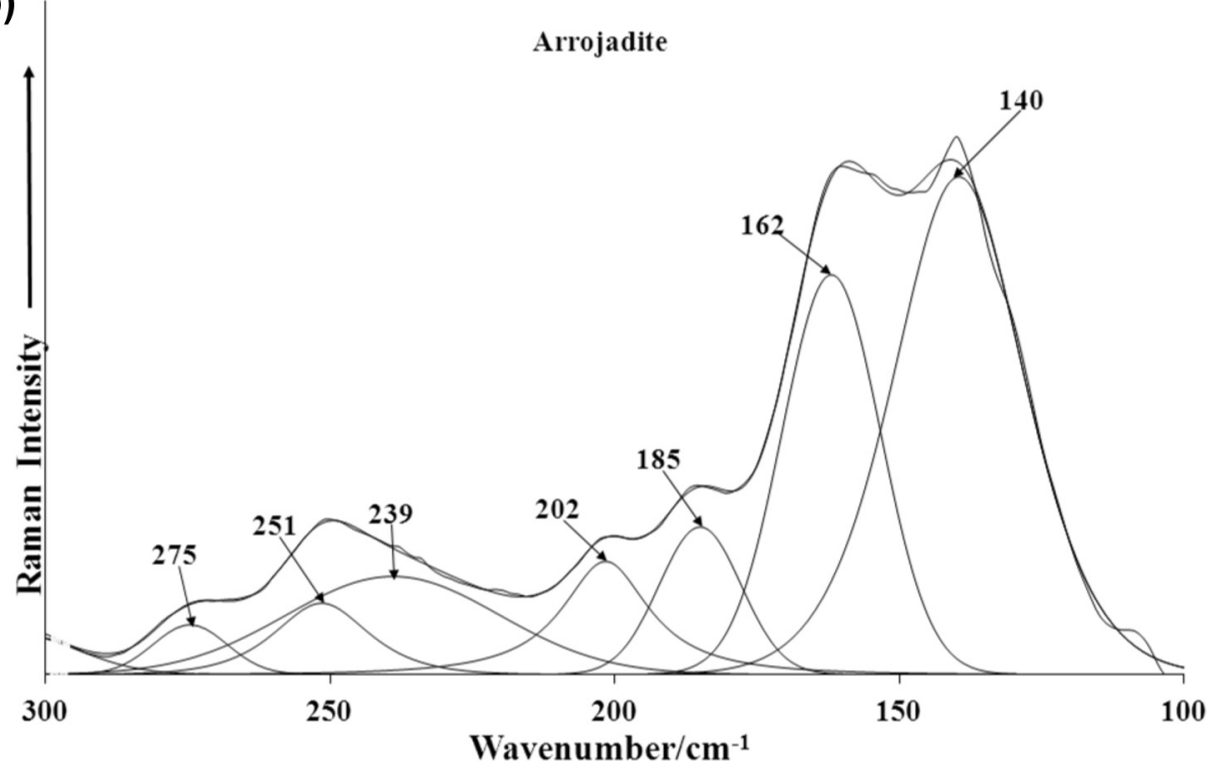

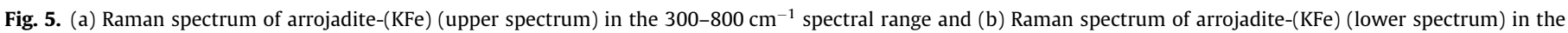
$100-300 \mathrm{~cm}^{-1}$ spectral range.

\section{Spectroscopy}

One most beneficial way of studying phosphate minerals is to undertake vibrational spectroscopy. In this way, the symmetry and distortion of the phosphate units in the mineral structure can be ascertained. Further, if there are different sometimes called non-equivalent phosphate units, then vibrational spectroscopy can determine if the phosphate units are identical or different. The Raman spectrum of arrojadite-(KFe) over the 100 to $3600 \mathrm{~cm}^{-1} \mathrm{spec}-$ tral region is displayed in Fig. 3a. This figure shows the position and relative intensity of the Raman bands. It is obvious that the less intense spectral region is over the $2600-4000 \mathrm{~cm}^{-1}$ region. This region is where the water and $\mathrm{OH}$ stretching vibrations are likely to be observed. The overall spectrum may be subdivided into sections depending upon the type of vibration being studied. The infrared spectrum over the $500-4000 \mathrm{~cm}^{-1}$ spectral range is shown in Fig. 3b.

The Raman spectrum of arrojadite-(KFe) in the 800 to $1400 \mathrm{~cm}^{-1}$ spectral range is reported in Fig. 4a. The Raman spec- trum shows complexity with a number of overlapping bands. Intense Raman bands are observed at 975,991 and $1005 \mathrm{~cm}^{-1}$ with shoulder bands at 951 and $1024 \mathrm{~cm}^{-1}$. These bands are assigned to the $\mathrm{PO}_{4}^{3-} \mathrm{v}_{1}$ symmetric stretching modes. Multiple bands are observed depending upon to which cation the phosphate is bonding. Raman bands are observed at 1024, 1066, 1092, 1123, 1148 and $1187 \mathrm{~cm}^{-1}$ and are assigned to the $\mathrm{PO}_{4}^{3-} v_{3}$ antisymmetric stretching modes. The Raman band at $975 \mathrm{~cm}^{-1}$ is attributed to the stretching vibrations of $\mathrm{HOPO}_{3}^{2-}$ units. The broad Raman band at $852 \mathrm{~cm}^{-1}$ is ascribed to water librational modes. Galy [20] first studied the polarized Raman spectra of the $\mathrm{H}_{2} \mathrm{PO}_{4}^{-}$anion. Choi et al. reported the polarization spectra of $\mathrm{NaH}_{2} \mathrm{PO}_{4}$ crystals. Casciani and Condrate [21] published spectra on brushite and monetite together with synthetic anhydrous monocalcium phosphate $\left(\mathrm{Ca}\left(\mathrm{H}_{2} \mathrm{PO}_{4}\right)_{2}\right)$, monocalcium dihydrogen phosphate hydrate $\left(\mathrm{Ca}\left(\mathrm{H}_{2}\right.\right.$ $\left.\left.\mathrm{PO}_{4}\right)_{2} \cdot \mathrm{H}_{2} \mathrm{O}\right)$ and octacalcium phosphate $\left(\mathrm{Ca}_{8} \mathrm{H}_{2}\left(\mathrm{PO}_{4}\right)_{6} \cdot 5 \mathrm{H}_{2} \mathrm{O}\right)$. These authors determined band assignments for $\mathrm{Ca}\left(\mathrm{H}_{2} \mathrm{PO}_{4}\right)$ and reported bands at 1002 and $1011 \mathrm{~cm}^{-1}$ as $\mathrm{POH}$ and $\mathrm{PO}$ stretching vibrations, respectively. The two Raman bands at 1086 and $1167 \mathrm{~cm}^{-1}$ are 
(a)

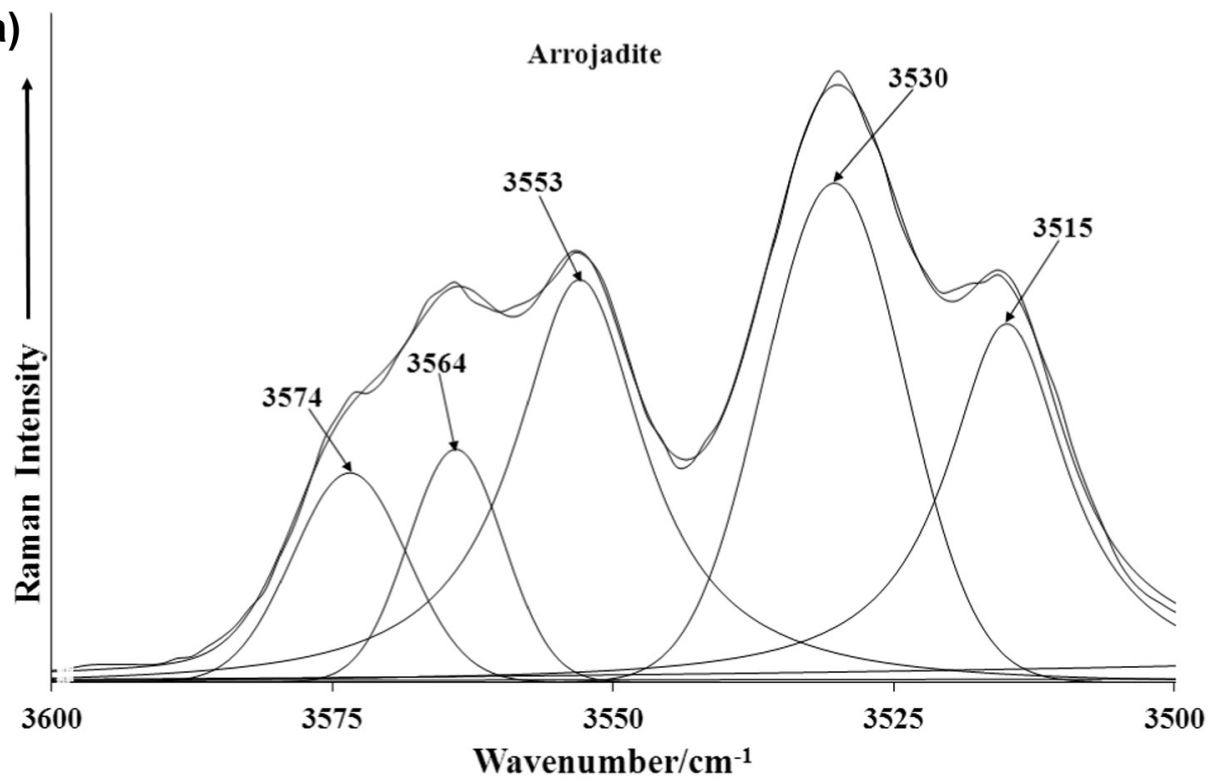

(b)

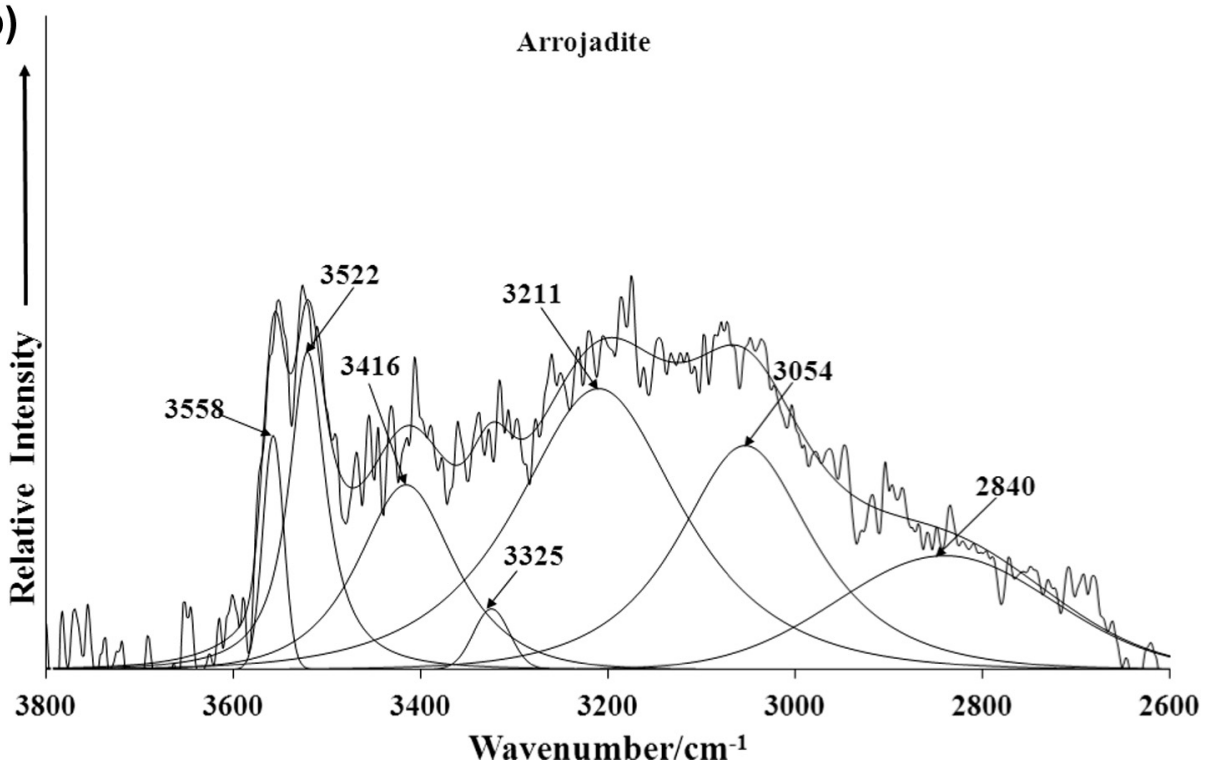

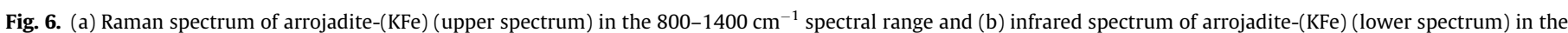
$500-1300 \mathrm{~cm}^{-1}$ spectral range.

attributed to both the HOP and PO antisymmetric stretching vibrations. Casciani and Condrate [21] tabulated Raman bands at 1132 and $1155 \mathrm{~cm}^{-1}$ and assigned these bands to $\mathrm{P}-\mathrm{O}$ symmetric and the $\mathrm{P}-\mathrm{O}$ antisymmetric stretching vibrations. The infrared spectrum displays greater complexity with multiple overlapping bands. The complexity of the spectrum makes it difficult to undertake band assignments.

The infrared spectrum of arrojadite-(KFe) in the 500 to $1300 \mathrm{~cm}^{-1}$ spectral region is displayed in Fig. 4b. The infrared spectrum displays greater complexity with multiple overlapping bands. The complexity of the spectrum makes it difficult to undertake band assignments. The infrared band at $1001 \mathrm{~cm}^{-1}$ is assigned to the $\mathrm{PO}_{4}^{3-} \mathrm{v}_{1}$ symmetric stretching vibration. The infrared bands at $1049,1079,1152$ and 1185 are attributed to the $\mathrm{PO}_{4}^{3-} v_{3}$ antisymmetric stretching vibrational mode. The infrared band at $835 \mathrm{~cm}^{-1}$ is ascribed to water librational modes. This complexity of both the Raman and infrared spectra may be due to a mixture of different phosphate anions, namely $\mathrm{PO}_{3}^{3-}, \mathrm{HOPO}_{3}^{2-}$ and $\mathrm{H}_{2} \mathrm{O}_{2} \mathrm{PO}^{-}$. There is a difference between taking a Raman spectrum and an infrared spec- trum. The sample spot size of the Raman spectrometer is around 1 micron. In infrared spectroscopy the measurement size is at best 30 microns. Thus in Raman spectroscopy it is possible to collect data for a pure mineral because that crystal was selected. It is more likely that the infrared spectrum is more likely to collect data for a mixture. This is why of course it is an advantage to run the Raman spectrum.

The Raman spectra of arrojadite-(KFe) in the 300 to $800 \mathrm{~cm}^{-1}$ and in the $100-300 \mathrm{~cm}^{-1}$ are displayed in Fig. 5a and b. The first spectral region is the region of the phosphate bending modes. This spectral region is where the $\mathrm{PO}_{4}^{3-}$ and $\mathrm{HOPO}_{3}^{2-}$ bending vibrations are found. A series of bands are observed at 540, 548, 557, 583, 604,615 and $638 \mathrm{~cm}^{-1}$. These bands are attributed to the $v_{4}$ out of plane bending modes of the $\mathrm{PO}_{4}$ and $\mathrm{H}_{2} \mathrm{PO}_{4}$ units. The Raman spectrum of crystalline $\mathrm{NaH}_{2} \mathrm{PO}_{4}$ shows Raman bands at 526, 546 and $618 \mathrm{~cm}^{-1}$ (this work). A series of bands are observed at 403 , $424,449,463,479$ and $513 \mathrm{~cm}^{-1}$. These bands are attributed to the $v_{2} \mathrm{PO}_{4}$ and $\mathrm{H}_{2} \mathrm{PO}_{4}$ bending modes. The Raman spectrum in the far wavenumber region is shown in Fig. 5b. Quite intense bands 

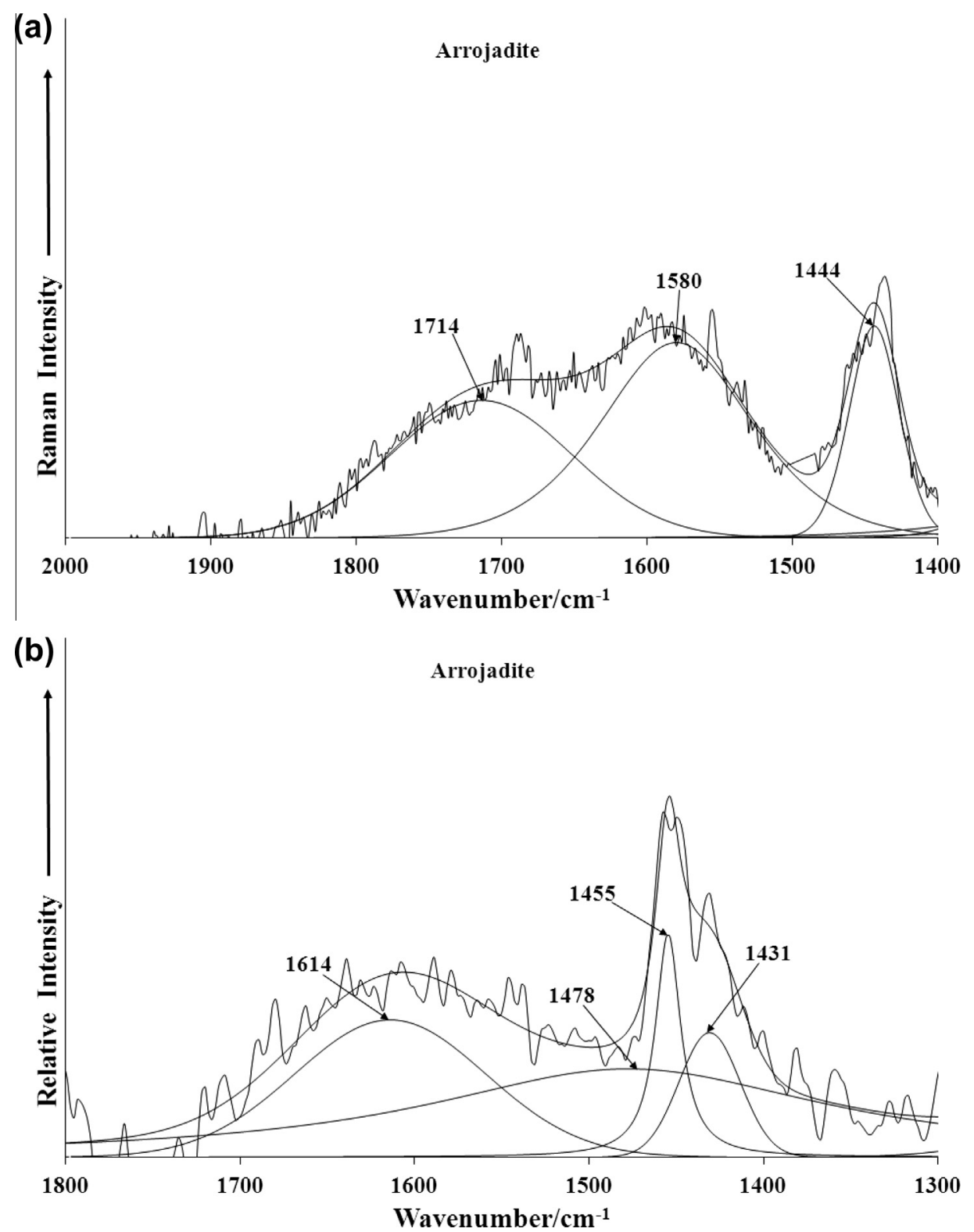

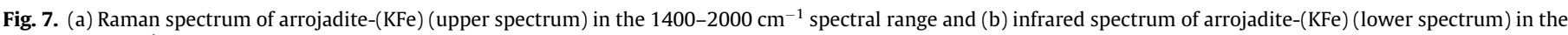
$1300-1800 \mathrm{~cm}^{-1}$ spectral range.

are found at $140,162,185,202,239,251$ and $275 \mathrm{~cm}^{-1}$. These bands may be simply described as lattice vibrations.

The Raman spectrum of the $\mathrm{OH}$ stretching region of arrojadite(KFe) is reported in Fig. 6a and b. The first figure shows the $\mathrm{OH}$ stretching bands and the second the water stretching bands. Raman bands are observed at 3515, 3560, 3553, 3564 and $3574 \mathrm{~cm}^{-1}$.

A comparison may be made with the infrared spectrum (Fig. 6b) where broad bands are observed at 2898, 3022, 3085, 3125, 3171 and $3268 \mathrm{~cm}^{-1}$, assigned to water stretching vibrational modes. It is noted that much greater intensity of the water bands is observed in the infrared spectrum as compared with the Raman spectrum. The reason for this is that water is a very poor Raman scatterer whereas water is a very strong infrared absorber. The Raman spectrum of arrojadite-(KFe) in the 1400 to $1800 \mathrm{~cm}^{-1}$ and the infrared spectrum in the 1300 to $1800 \mathrm{~cm}^{-1}$ are shown in Fig. 7a and $\mathrm{b}$. This spectral region is where the water bending modes are observed. The Raman spectrum shows a reasonably strong band at $1631 \mathrm{~cm}^{-1}$ assigned to the water bending mode. A similar intense band at $1632 \mathrm{~cm}^{-1}$ is observed in the infrared spectrum. Other infrared bands are found at 1426 and $1575 \mathrm{~cm}^{-1}$.

\section{Conclusions}

We have characterized the mineral arrojadite-(KFe) using vibrational spectroscopic techniques with support of SEM/EDS chemical analysis. The chemical formula was calculated on the basis of 500 atoms $(\mathrm{O}, \mathrm{OH})$ and can be expressed as:

$$
\begin{aligned}
& \mathrm{K}_{2.06} \mathrm{Na}_{2} \mathrm{Ca}_{0.89} \mathrm{Na}_{3.23}\left(\mathrm{Fe}_{7.82} \mathrm{Mg}_{4.40} \mathrm{Mn}_{0.78}\right)_{\Sigma 13.00} \mathrm{Al}_{1.44}\left(\mathrm{PO}_{4}\right)_{10.85} \\
& \quad\left(\mathrm{PO}_{3} \mathrm{OH}_{0.23}\right)(\mathrm{OH})_{2} .
\end{aligned}
$$

The results indicate an arrojadite-(KFe) mineral.

The mineral is characterized by an intense sharp Raman bands at $1009 \mathrm{~cm}^{-1}$ with shoulders at 975,991 and $1005 \mathrm{~cm}^{-1}$ are assigned to stretching vibrations of $\mathrm{PO}_{4}^{3-}$ and $\mathrm{HPO}_{4}^{2-}$ units. Raman band at $991 \mathrm{~cm}^{-1}$ is assigned to the $v_{1}$ symmetric stretching mode 
of the $\mathrm{POH}$ units, whereas the Raman band at $1005 \mathrm{~cm}^{-1}$ is assigned to the $v_{1} \mathrm{PO}_{4}^{3-}$ symmetric stretching mode. Raman bands observed at 540,548,557, 583, 604, 615 and $638 \mathrm{~cm}^{-1}$ are attributed to the $v_{4}$ out of plane bending modes of the $\mathrm{PO}_{4}$ and $\mathrm{H}_{2} \mathrm{PO}_{4}$ units.

The Raman bands at 3515, 3560, 3553, 3564 and $3574 \mathrm{~cm}^{-1}$ are assigned to water and hydroxyl stretching vibration. A comparison may be made with the infrared spectrum where broad bands are observed at 2898, 3022, 3085, 3125, 3171 and $3268 \mathrm{~cm}^{-1}$, assigned to water stretching vibrational modes. The observation of multiple bands gives credence to the non-equivalence of the water units in the arrojadite-(KFe) structure.

\section{Acknowledgements}

The financial and infra-structure support of the Discipline of Nanotechnology and Molecular Science, Science and Engineering Faculty of the Queensland University of Technology, is gratefully acknowledged. The Australian Research Council (ARC) is thanked for funding the instrumentation. The authors would like to acknowledge the Center of Microscopy at the Universidade Federal de Minas Gerais (http://www.microscopia.ufmg.br) for providing the equipment and technical support for experiments involving electron microscopy. R. Scholz thanks to FAPEMIG - Fundação de Amparo à Pesquisa do Estado de Minas Gerais, (Grant No. CRA APQ-03998-10). L.F.C. Horta thanks to PET/Geologia/UFOP.

\section{Appendix A. Supplementary material}

Supplementary data associated with this article can be found, in the online version, at http://dx.doi.org/10.1016/j.saa.2013.02.027.

\section{References}

[1] F. Camara, R. Oberti, C. Chopin, O. Medenbach, Am. Mineral. 91 (2006) 1249_ 1259.

[2] C. Chopin, R. Oberti, F. Camara, Am. Mineral. 91 (2006) 1260-1270.

[3] V.M. Krutik, D.Y. Pushcharovskii, E.A. Pobedimskaya, N.V. Belov, Kristallografiya 24 (1979) 743-750.

[4] S. Merlino, M. Mellini, P.F. Zanazzi, Acta Crystallogr. Sect. B 37 (1981) 17331736.

[5] P.B. Moore, T. Araki, S. Merlino, M. Mellini, P.F. Zanazzi, Am. Mineral. 66 (1981) 1034-1049.

[6] I.M. Steele, in: 18th General Meeting of the International Mineralogical Association, Edinburgh, UK, 2002, p. 117.

[7] O.V. Yakubovich, E.N. Matvienko, M.A. Simonov, O.K. Mel'nikov, Vest. Mosk. Univ. Seriya 4: Geologiya, 1986, pp. 36-47.

[8] M.L. Lindberg, Am. Mineral. 35 (1950) 59-76.

[9] L.N. Dias, M.V.B. Pinheiro, R.L. Moreira, K. Krambrock, K. Guedes, L.A.D.M. Filho, J. Karfunkel, J. Schnellrath, R. Scholz, Am. Mineral. 96 (2011) 42-52.

[10] R.L. Frost, Y. Xi, J. Mol. Struct. 1010 (2012) 179-183.

[11] R.L. Frost, Y. Xi, S.J. Palmer, R. Pogson, Spectrochim. Acta. A 82 (2011) 461-466.

[12] R.L. Frost, Y. Xi, S.J. Palmer, R.E. Pogson, Spectrochim. Acta. A 83 (2011) 106111.

[13] V.C. Farmer, Mineralogical Society Monograph 4: The Infrared Spectra of Minerals, The Mineralogical Society, London, 1974.

[14] R.L. Frost, T. Kloprogge, P.A. Williams, W. Martens, T.E. Johnson, P. Leverett, Spectrochim. Acta. A 58 (2002) 2861-2868.

[15] R.L. Frost, W. Martens, P.A. Williams, J.T. Kloprogge, Mineral. Mag. 66 (2002) 1063-1073.

[16] R.L. Frost, W.N. Martens, T. Kloprogge, P.A. Williams, Neues Jahr. Min. (2002) 481-496.

[17] R.L. Frost, P.A. Williams, W. Martens, J.T. Kloprogge, P. Leverett, J. Raman Spectrosc. 33 (2002) 260-263.

[18] R.L. Frost, M.L. Weier, J. Mol. Struct. 697 (2004) 207-211.

[19] F.G. Young, The mid-Cretaceous flysch and phosphatic ironstone sequence, northern Richardson Mountains, Yukon Territory, Report of Activities, Geological Survey of Canada, vol. 77-1C, 1977, pp. 67-74.

[20] A. Galy, J. Phys. Rad. 12 (1951) 827

[21] F.S. Casciani, R.A. Condrate, Sr., The infrared and Raman spectra of several calcium hydrogen phosphates, in: Proceedings - International Congress on Phosphorus Compounds, second ed., 1980, pp. 175-190. 